\title{
Habitat use in Atlantic bluefin tuna Thunnus thynnus inferred from diving behavior
}

\author{
Steven G. Wilson*, Barbara A. Block \\ Tuna Research and Conservation Center, Hopkins Marine Station, Stanford University, 120 Oceanview Blvd, \\ Pacific Grove, California 93950, USA
}

\begin{abstract}
To examine habitat use in Atlantic bluefin tuna Thunnus thynnus, we used time series records from 20 archival tags and 7 pop-up satellite archival tags. Daily vertical profiles were classified into 3 dive types: (1) profiles restricted to surface waters by either bathymetry or thermal constraints; (2) profiles with frequent V-shaped dives that may be associated with transiting or searching behaviors; and (3) U-shaped profiles associated with putative foraging behavior. Fixed kernel probability contours were calculated for each of the dive profile classes. Key potential North Atlantic foraging habitats were identified in the NW Atlantic (Gulf of Maine/Scotian Shelf, Grand Banks and Flemish Cap), off Florida and the Bahamas and in the NE Atlantic. These 'hotspot' regions encompass areas of high seas that may be important to future conservation and management of the species. U-shaped dive profiles were shallower and surface returns were more frequent in areas where subsurface temperatures were coldest. The presence of Atlantic bluefin tuna coincided with peak productivity and sea surface temperatures in 3 of the 5 hotspot areas. Further analyses examined spatial and temporal patterns of transatlantic migrations and deep diving behavior in the Strait of Gibraltar.
\end{abstract}

KEY WORDS: Bluefin tuna $\cdot$ Dive classification $\cdot$ U-shaped dives $\cdot$ Habitat use $\cdot$ Hotspots

\section{INTRODUCTION}

Atlantic bluefin tuna Thunnus thynnus are a highly migratory species inhabiting coastal and pelagic waters throughout the North Atlantic Ocean. They are managed by the International Commission for the Conservation of Atlantic Tunas as 2 stocks separated by the $45^{\circ} \mathrm{W}$ meridian, with discrete spawning grounds. Conventional and electronic tagging studies, however, have demonstrated that bluefin frequently cross between the 2 management areas (e.g. NRC 1994, Block et al. 2005). Habitats occupied by Atlantic bluefin include those essential for breeding and foraging. Other areas are briefly transited when moving between spawning grounds and seasonal feeding areas.

Over the past few decades, biologging instruments have been attached to, or implanted in, a wide variety of marine animals, ranging from blue whales (Croll et al. 2001) to albatrosses (Huin \& Prince 1997) to jellyfish (Hays et al. 2008). Large numbers of dive profiles have been generated during this time, yet our understand- ing of the functions of different dive types remains limited. Recently, however, a general thrust among behavioral and physiological ecologists has been to link dive profiles to information on the behavior and physiology of animals during dives (Blank et al. 2004, Hassrick et al. 2007, Hays 2008). For example, specific patterns in vertical diving and thermal maxima have been identified in Atlantic bluefin on their Gulf of Mexico spawning grounds (Teo et al. 2007a,b). The putative spawning behavior includes oscillatory diving at night in waters of surface temperature $>24^{\circ} \mathrm{C}$ and internal body temperatures that often peak just before dawn. Such behaviors may be indicative of increased activity associated with courtship or spawning.

Several methods have been developed to distinguish foraging areas from transited areas in electronic data records, such as linearity of a movement path (Spencer et al. 1990) and the presence of visceral warming following the ingestion of food (Kitagawa et al. 2004, Walli 2007, Bestley et al. 2008). However, deep foraging dives often result in flattened light curves and the 
lack of geolocation estimates, thereby preventing analyses of linearity during foraging periods. Visceral warming, a potential indicator of foraging activity, can be masked by thermal inertia in large fish, thus preventing the identification of individual feeding events. New, more robust techniques are needed to distinguish different habitat uses in large pelagic fishes.

Dive classification analysis was originally based solely on maximum depth and dive duration (e.g. Kooyman 1968). More recent studies have used the shape of dives (depth versus time) to distinguish different behavioral states (e.g. Baechler et al. 2002). For example, $\mathrm{V}$-shaped dives are thought to characterize the vertical behavior of animals that are transiting areas or searching for prey. By moving up and down in the water column rather than at a constant depth, traveling animals may decrease drag (Williams \& Kooyman 1985) and reduce the metabolic costs of locomotion. Animals in this search mode may also increase prey encounter rates without significantly increasing their travel distance (Thompson et al. 1991). In contrast, U-shaped dives (also called square-shaped dives) are thought to represent animals locating and exploiting aggregated prey for extended periods each day (Lesage et al. 1999, Schreer et al. 2001, Baechler et al. 2002). To date, most dive classification research has focused on air-breathing marine vertebrates, including pinnepeds (e.g. Schreer et al. 2001), cetaceans (e.g. Martin et al. 1994), sirenians (Chilvers et al. 2004), turtles (e.g. Fossette et al. 2008) and penguins (e.g. Wilson et al. 1996), while comparatively little attention has been given to similar dive patterns in large pelagic fishes. Although this can be attributed to the gill-breathers' necessity for remaining completely submerged and the challenges thus involved in classifying a dive, the high resolution time series records obtainable with electronic tags indicate that substantial behavioral patterns exist.

The classification of different dives identified in data records depends on the method used to differentiate them. These range from manual classification to statistical methods, such as cluster analysis (Tinker et al. 2007), principal component analysis (Schreer \& Testa 1995), discriminant function analysis (Baechler et al. 2002) and artificial neural networks (Schreer et al. 1998). Statistical analyses apply rigid criteria to dive data, providing advantages in terms of objectivity and efficiency. Manual techniques focus on the geometry, depth and duration of dives and tend to assign a purpose to each dive type that is identified (Malcolm \& Duffus 2000). Comparative studies have shown manual classification to be as good as or better than statistical analyses at identifying subtle differences in dive profiles, which may be indicative of behavioral differences (Schreer \& Testa 1996, Malcolm \& Duffus 2000). Consequently, many researchers choose manual clas- sification coupled with an understanding of the behavior and ecology of the animal over statistical alternatives (e.g. Hays et al. 2000, Lescroël \& Bost 2005, Crocker et al. 2006, Hassrick et al. 2007, Schaefer et al. 2007, Elliott et al. 2008). In the present study, we used the spatial distribution of manually classified dive profiles to infer habitat use in Atlantic bluefin tuna.

\section{MATERIALS AND METHODS}

Tagging. As of December 2008, the Tag-A-Giant program of Stanford University and the Monterey Bay Aquarium has deployed over 1000 electronic tags on Atlantic bluefin tuna. Of these, 637 were archival tags and $127(19.9 \%)$ have been returned. To avoid any eastern or western bias, only tag data sets from bluefin tuna that crossed the $45^{\circ} \mathrm{W}$ meridian separating eastern and western management areas were selected for analysis and examined in detail. Tag archival records from 27 fish met these criteria, 20 from surgically implanted archival tags (Northwest Marine Technology v1.1 and Wildlife Computers Mk 7 or Lotek Wireless LTD 2310) deployed off North Carolina and 7 from popup satellite archival tags (Wildlife Computers) deployed off North Carolina and Ireland (Table 1). Each of these fish was caught by rod and reel, brought aboard the vessel, measured, tagged and released. The implantable archival tags were surgically implanted into the peritoneal cavity of the fish using procedures previously described (Block et al. 1998a). The pop-up satellite archival tags were attached externally at the base of their second dorsal fins with a titanium dart and monofilament leader that penetrated to a depth of $14 \mathrm{~cm}$ (Block et al. 1998b). The dive classification component of this study was limited to high resolution (1 or $2 \mathrm{~min}$ ) time series data records of depth, ambient light levels, internal and external temperatures. This criterion was met by 16 of the 27 tag records (Table 1 ).

Stock identity was assigned when fish occupied a known eastern or western spawning ground with sea surface temperatures (SST) $>24^{\circ} \mathrm{C}$ for an extended period during the breeding season (Block et al. 2005). Spawning ground visitation was determined from the tag records or recapture locations (in cases where the battery was spent). Eleven fish were of eastern origin, 4 were of western origin and 12 were of unknown origin, i.e. they did not visit a known spawning ground while tagged.

Analysis. Light-level data from recovered tags was processed (either onboard the tag or using software provided by the tag manufacturer) to provide longitude estimates based on the time of local noon or midnight. Daily latitude estimates were calculated by matching tag SSTs with remotely sensed SSTs (Teo et 
Table 1. Thunnus thynnus. Atlantic bluefin tuna selected for inclusion in pelagic habitat use study. Dates are given as mo/d/yr. CFL: curved fork length

\begin{tabular}{|c|c|c|c|c|c|c|}
\hline \multirow[t]{2}{*}{ Fish ID } & \multirow{2}{*}{$\begin{array}{l}\text { CFL } \\
\text { (cm) }\end{array}$} & \multirow{2}{*}{$\begin{array}{c}\text { Stock } \\
\text { identity }\end{array}$} & \multicolumn{2}{|c|}{-Tagging } & \multicolumn{2}{|c|}{ - Recapture } \\
\hline & & & Date & Location & Date & Location \\
\hline 5197031 & 203 & East & $3 / 3 / 1997$ & $35.09^{\circ} \mathrm{N}, 75.26^{\circ} \mathrm{W}$ & $6 / 15 / 2000$ & $35.37^{\circ} \mathrm{N}, 12.53^{\circ} \mathrm{E}$ \\
\hline $5199104^{a}$ & 227 & East & 12/31/1998 & $34.55^{\circ} \mathrm{N}, 76.37^{\circ} \mathrm{W}$ & $5 / 5 / 2001$ & $35.47^{\circ} \mathrm{N}, 6.17^{\circ} \mathrm{W}$ \\
\hline $5100107^{a}$ & 219 & West & 1/1/1999 & $34.58^{\circ} \mathrm{N}, 76.37^{\circ} \mathrm{W}$ & $4 / 6 / 2000$ & $37.41^{\circ} \mathrm{N}, 19.72^{\circ} \mathrm{W}$ \\
\hline $5100117^{a}$ & 214 & - & 1/14/1999 & $34.63^{\circ} \mathrm{N}, 76.3^{\circ} \mathrm{W}$ & $4 / 26 / 2001$ & $29.31^{\circ} \mathrm{N}, 13.08^{\circ} \mathrm{W}$ \\
\hline $5100127^{\mathrm{a}}$ & 217 & West & 1/16/1999 & $34.51^{\circ} \mathrm{N}, 76.64^{\circ} \mathrm{W}$ & $8 / 8 / 2000$ & $42.00^{\circ} \mathrm{N}, 70.00^{\circ} \mathrm{W}$ \\
\hline 5100135 & 191 & East & 1/17/1999 & $34.55^{\circ} \mathrm{N}, 76.65^{\circ} \mathrm{W}$ & $7 / 2 / 2003$ & $38.46^{\circ} \mathrm{N}, 0.98^{\circ} \mathrm{E}$ \\
\hline 5100143 & 218 & East & 1/20/1999 & $34.50^{\circ} \mathrm{N}, 76.67^{\circ} \mathrm{W}$ & $6 / 3 / 2001$ & $38.36^{\circ} \mathrm{N}, 2.27^{\circ} \mathrm{E}$ \\
\hline $5100148^{\mathrm{a}}$ & 208 & West & 1/21/1999 & $34.51^{\circ} \mathrm{N}, 76.66^{\circ} \mathrm{W}$ & $10 / 15 / 2000$ & $52.03^{\circ} \mathrm{N}, 32.14^{\circ} \mathrm{W}$ \\
\hline 5100205 & 222 & East & 2/11/1999 & $34.40^{\circ} \mathrm{N}, 76.59^{\circ} \mathrm{W}$ & 8/31/2002 & $35.95^{\circ} \mathrm{N}, 5.55^{\circ} \mathrm{W}$ \\
\hline 5101314 & 206 & - & $1 / 12 / 2001$ & $34.65^{\circ} \mathrm{N}, 76.41^{\circ} \mathrm{W}$ & $7 / 2 / 2001$ & $47.00^{\circ} \mathrm{N}, 42.30^{\circ} \mathrm{W}$ \\
\hline $5102410^{\mathrm{a}}$ & 201 & East & $2 / 1 / 2002$ & $35.04^{\circ} \mathrm{N}, 76.00^{\circ} \mathrm{W}$ & $11 / 30 / 2004$ & $35.95^{\circ} \mathrm{N}, 5.49^{\circ} \mathrm{W}$ \\
\hline 5103422 & 210 & - & $1 / 13 / 2003$ & $34.40^{\circ} \mathrm{N}, 76.53^{\circ} \mathrm{W}$ & 8/8/2003 & $45.90^{\circ} \mathrm{N}, 4.99^{\circ} \mathrm{W}$ \\
\hline 5103425 & 209 & - & $1 / 16 / 2003$ & $34.66^{\circ} \mathrm{N}, 76.31^{\circ} \mathrm{W}$ & $8 / 12 / 2003$ & $47.83^{\circ} \mathrm{N}, 23.77^{\circ} \mathrm{W}$ \\
\hline $5103497^{\mathrm{a}}$ & 208 & East & $1 / 16 / 2003$ & $34.54^{\circ} \mathrm{N}, 76.32^{\circ} \mathrm{W}$ & $12 / 6 / 2006$ & $36.05^{\circ} \mathrm{N}, 14.46^{\circ} \mathrm{E}$ \\
\hline $5103498^{\mathrm{a}}$ & 205 & - & $1 / 16 / 2003$ & $34.54^{\circ} \mathrm{N}, 76.31^{\circ} \mathrm{W}$ & $4 / 30 / 2007$ & $34.45^{\circ} \mathrm{N}, 6.95^{\circ} \mathrm{W}$ \\
\hline $5103508^{\mathrm{a}}$ & 209 & East & $1 / 18 / 2003$ & $34.49^{\circ} \mathrm{N}, 76.27^{\circ} \mathrm{W}$ & $6 / 10 / 2006$ & $33.48^{\circ} \mathrm{N}, 19.93^{\circ} \mathrm{E}$ \\
\hline $5103539^{a}$ & 195 & - & $1 / 25 / 2003$ & $34.55^{\circ} \mathrm{N}, 76.32^{\circ} \mathrm{W}$ & $5 / 13 / 2007$ & $36.15^{\circ} \mathrm{N}, 5.91^{\circ} \mathrm{W}$ \\
\hline $5104484^{\mathrm{a}}$ & 222 & - & $1 / 9 / 2004$ & $34.51^{\circ} \mathrm{N}, 76.25^{\circ} \mathrm{W}$ & $1 / 1 / 2006$ & Unknown \\
\hline $5104497^{a}$ & 219 & West & $1 / 14 / 2004$ & $34.52^{\circ} \mathrm{N}, 76.21^{\circ} \mathrm{W}$ & $3 / 12 / 2008$ & $26.36^{\circ} \mathrm{N}, 94.19^{\circ} \mathrm{W}$ \\
\hline 5104458 & 236 & - & $1 / 16 / 2004$ & $34.43^{\circ} \mathrm{N}, 76.25^{\circ} \mathrm{W}$ & $7 / 23 / 2004$ & $46.19^{\circ} \mathrm{N}, 11.63^{\circ} \mathrm{W}$ \\
\hline $5104516^{\mathrm{a}}$ & 218 & East & $1 / 17 / 2004$ & $34.44^{\circ} \mathrm{N}, 76.15^{\circ} \mathrm{W}$ & $4 / 20 / 2005$ & $42.16^{\circ} \mathrm{N}, 9.74^{\circ} \mathrm{W}$ \\
\hline $5104559^{a}$ & 230 & East & $10 / 8 / 2004$ & $55.42^{\circ} \mathrm{N}, 7.47^{\circ} \mathrm{W}$ & $6 / 12 / 2005$ & $31.57^{\circ} \mathrm{N}, 17.42^{\circ} \mathrm{E}$ \\
\hline $5105027^{\mathrm{a}}$ & 229 & East & $1 / 5 / 2005$ & $34.32^{\circ} \mathrm{N}, 76.59^{\circ} \mathrm{W}$ & $6 / 2 / 2007$ & $31.43^{\circ} \mathrm{N}, 17.55^{\circ} \mathrm{E}$ \\
\hline $5105032^{\mathrm{a}}$ & 223 & - & $1 / 5 / 2005$ & $34.34^{\circ} \mathrm{N}, 76.63^{\circ} \mathrm{W}$ & $9 / 25 / 2006$ & $47.65^{\circ} \mathrm{N}, 10.30^{\circ} \mathrm{W}$ \\
\hline 5105010 & 247 & - & $1 / 10 / 2005$ & $34.39^{\circ} \mathrm{N}, 76.58^{\circ} \mathrm{W}$ & $9 / 8 / 2005$ & $46.91^{\circ} \mathrm{N}, 61.88^{\circ} \mathrm{W}$ \\
\hline 5105022 & 237 & - & $1 / 12 / 2005$ & $34.45^{\circ} \mathrm{N}, 76.28^{\circ} \mathrm{W}$ & $9 / 8 / 2005$ & $55.36^{\circ} \mathrm{N}, 24.46^{\circ} \mathrm{W}$ \\
\hline 5105025 & 232 & - & $1 / 26 / 2005$ & $34.62^{\circ} \mathrm{N}, 76.32^{\circ} \mathrm{W}$ & $9 / 22 / 2005$ & $55.92^{\circ} \mathrm{N}, 29.70^{\circ} \mathrm{W}$ \\
\hline
\end{tabular}

al. 2004). Following these methods, Teo et al. (2004) found root mean square errors of $0.78^{\circ}$ and $1.30^{\circ}$ for longitude estimates and $0.90^{\circ}$ and $1.89^{\circ}$ for latitude estimates from archival and pop-up satellite archival tags, respectively, attached to Atlantic bluefin tuna. Gaps in daily location data were filled in by linear interpolation using code written for Matlab R2007b. Over $90 \%$ of the gaps were of $4 \mathrm{~d}$ or less, and interpolated locations represented $35 \%$ of the total locations.

Daily depth profiles of each fish were manually classified (Figs. 1 \& 2) into 1 of 3 dive types: (1) profiles restricted to surface waters-allows for occasional bounce dives, sometimes to significant depth, provided that a great majority of the time is spent in surface waters; (2) V-shaped profiles - irregular profiles with frequent bounce dives and no obvious diel patterns; and (3) U-shaped profiles with or without surface returns - regular profiles in which daytime depths are significantly deeper than at night and modal depths are consistent over consecutive days. The investigator that performed the manual dive classification was unaware of the geolocation data associated with each daily dive profile.
Spatial analysis of the data was conducted in ArcView 3.2 and ArcGIS 9.2 (Environmental Systems Research Institute). Fixed kernel probability contours were created for the pooled locations of restricted, Vshaped and U-shaped profiles using the Animal Movement Analysis extension for ArcView (Hooge \& Eichenlaub 2000). Contour smoothing parameters were calculated using the least-square crossvalidation method (Silverman 1986).

Dive statistics were calculated using code written for Matlab R2007b (Lawson et al. 2010). Dives were defined as starting when fish descended below a depth of $70 \mathrm{~m}$ and as ending when they ascended above a depth of $50 \mathrm{~m}$. Only dives starting and ending during daylight hours $( \pm 1 \mathrm{~h})$ were included in this analysis because visual predators, such as Atlantic bluefin tuna, primarily feed during daylight hours. For each day, the code calculated the number of dives, mean dive duration over all dives, mean inter-dive interval over all dives, mean depth between the first and last inflection points over all dives, maximum depth over all dives and the minimum, maximum and mean temperatures over all dives. 


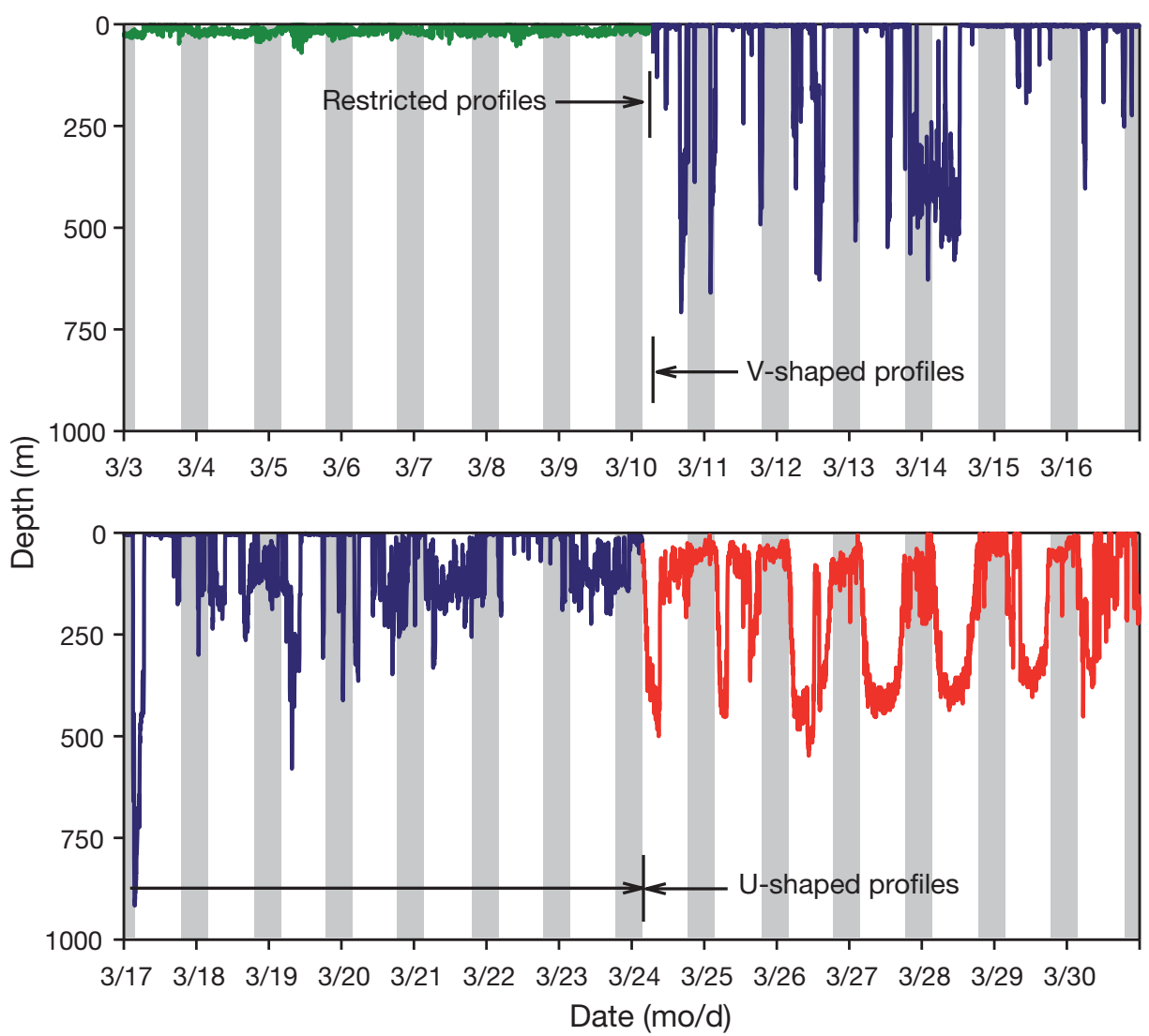

Fig. 1. Thunnus thynnus. A 4 wk time series of depth data from Fish 5100107 moving from coastal waters off North Carolina to the outer continental shelf off New England, USA. Shaded areas indicate nighttime. For details of the 3 profile types see 'Materials and methods: Analysis'

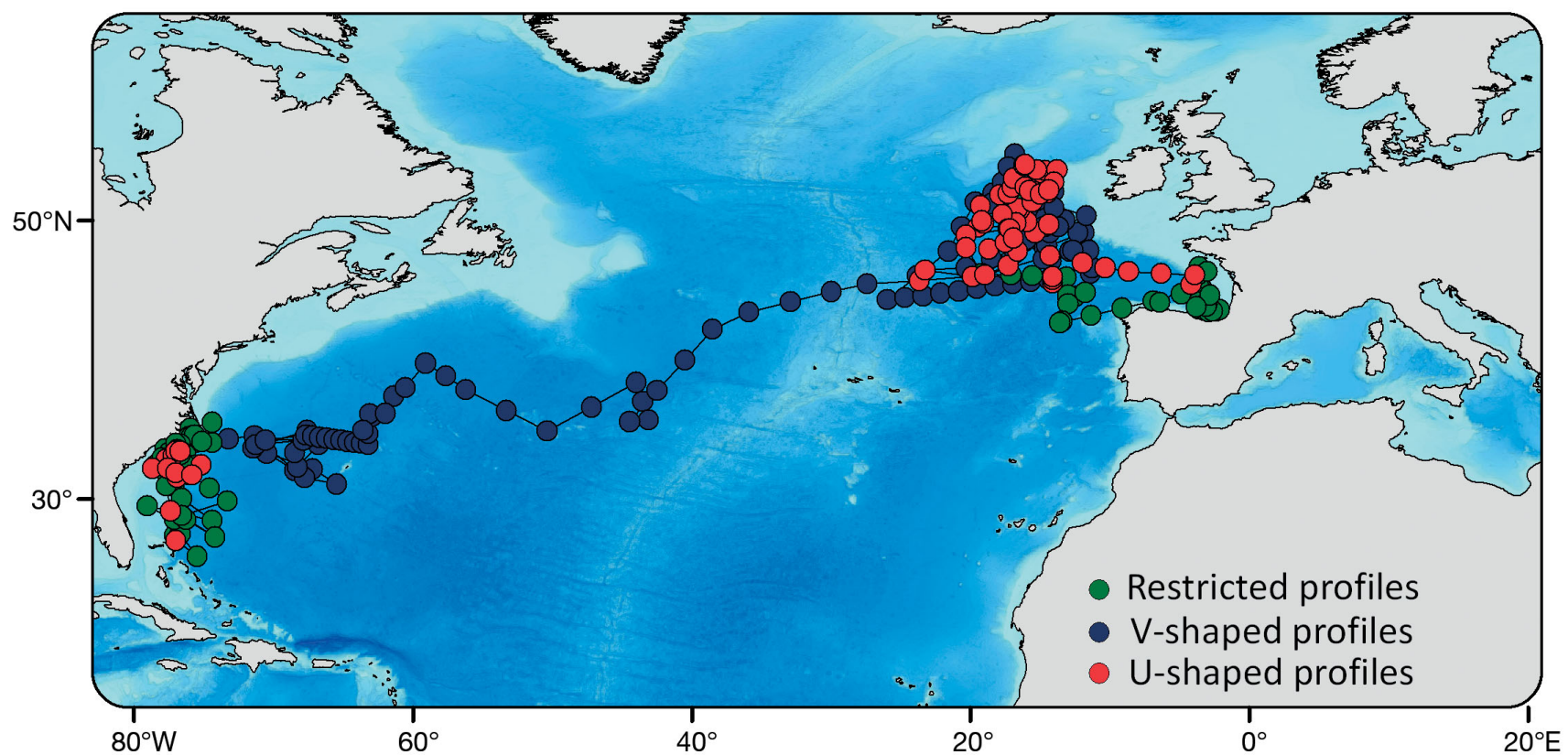

Fig. 2. Thunnus thynnus. Track from Fish 5103497 showing manually classified daily dive profiles 
Level 3 MODIS Aqua monthly (2003 to 2007) composite SST data (11 $\mu \mathrm{m}$ nighttime) and net primary production data (Behrenfeld \& Falkowski 1997) were used to compare temporal patterns in the oceanography of the foraging hotspots (available at: http://oceancolor. gsfc.nasa.gov/). Code written for Matlab R2007b used hotspot boundary polygons to select the satellite data and calculate monthly environmental statistics for each area.

\section{RESULTS}

The electronic tag records examined were from Atlantic bluefin tuna that ranged in length from 191 to $247 \mathrm{~cm}$ at release (Table 1). Manual dive classification sorted the depth records into 3 types of daily profiles: restricted $(31.1 \%, \mathrm{n}=2152 \mathrm{~d}), \mathrm{V}$-shaped $(39.1 \%, \mathrm{n}=$ $2706 \mathrm{~d})$ and U-shaped dives $(29.8 \%, \mathrm{n}=2067 \mathrm{~d})$. Restricted profiles were predominantly found in shallow, coastal areas and in colder, northern regions (Fig. 3a). Fixed kernel probability contours of the pooled restricted profile locations were centered on North Carolina and the Gulf of Maine. V-shaped profiles, interpreted as putative transiting or searching behavior, were distributed across the range of Atlantic bluefin, particularly in regions of the open ocean (Fig. 3b). Finally, U-shaped profiles extended in a broad arc from Florida to offshore waters of western Europe. Areas where large numbers of U-shaped dives occur are potentially foraging hotspots. The locations where these dives occur are in the NW Atlantic (the Gulf of Maine, Grand Banks and Flemish Cap), off Florida and the Bahamas and in the NE Atlantic (Fig. 3c).

Daytime U-shaped dive profiles were deepest (mean depth: 117.41-203.84 m) and individual dives longest (mean duration: 0.96-1.58 h) in waters off Florida and the Bahamas and in the NE Atlantic hotspot area, where the mixed layer was deep and water temperatures at depth were warmest (mean minimum temperature: $11.27-12.13^{\circ} \mathrm{C}$ ) (Table 2, Fig. 4). In the NW Atlantic, where sub-surface water temperatures were colder (mean minimum temperature: $1.43-7.17^{\circ} \mathrm{C}$ ), dive profiles were shallower (mean depth: 77.25$113.77 \mathrm{~m}$ ) and surface returns were more frequent (mean duration: 0.21-0.89 h). The occurrence of Atlantic bluefin tuna in 3 of the 5 hotspot areas coincided with peak primary productivity at those locations, with the exceptions being the Gulf of Maine/ Scotian Shelf and the Flemish Cap (Fig. 5). Bluefin presence corresponded with peak SSTs in the $3 \mathrm{NW}$ Atlantic hotspot areas, but not in the waters off Florida and the Bahamas or in the NE Atlantic.

Nineteen west to east transatlantic migrations were identified in the data records (Fig. 6). The transatlantic crossings originated along the eastern seaboard of the United States (from the Straits of Florida to the Gulf of
Maine) between February and June and terminated off western Europe (from the Strait of Gibraltar to Ireland) between April and August. The movements were generally from the southwest to the northeast and ranged in duration from 33 to $133 \mathrm{~d}$ (mean duration: $79 \mathrm{~d}$ ). Bluefin transiting from west to east took a more southerly route when departing shelf waters earlier in the year than later in the year.

Six tag records showed bluefin tuna entering the Mediterranean Sea at least once (in May and early June), ahead of the eastern stock's June to July breeding season (Rooker et al. 2007). Depth records were available for 2 of those movements, and both fish repeatedly made deep bounce dives to depths of almost $1000 \mathrm{~m}$ as they passed through the Strait of Gibraltar (Fig. 7).

\section{DISCUSSION}

Previous studies have shown that Atlantic bluefin tuna Thunnus thynnus utilize habitats throughout the North Atlantic Ocean, Gulf of Mexico and Mediterranean Sea (e.g. Block et al. 2005, Wilson et al. 2005, Walli et al. 2009). How they use distinct regions of this range may be clarified by examining detailed dive profiles available in the archival tag records of tagged fish. Here we used 3 frequently observed dive patterns as proxies for different habitat uses in bluefin tuna inhabiting the North Atlantic Ocean.

Most of the restricted profiles identified in the dive records of tagged bluefin, particularly those occurring in warm, coastal areas, were bathymetrically constrained (Fig. 3a). However, in cold, offshore areas, some fish appeared to be thermally constrained, i.e. they remained in surface waters to avoid cold subsurface waters.

V-shaped dive profiles were the most abundant of the 3 diving types. Fish transiting an area or searching for prey may use this type of dive as their routine type of locomotory movement. Fixed kernel probability contours of the pooled V-shaped profile locations roughly coincided with the spatial extent of the Sargasso Sea, a biologically unproductive region bounded by the North Atlantic Subtropical Gyre (Fig. 3b). Bluefin conventionally tagged off the Bahamas in the 1960s and 1970s and recaptured months later off Norway were emaciated, suggesting a lack of feeding opportunities during their transatlantic movement (Mather 1980). The stomachs of a large percentage (65\%) of bluefin captured in the western Sargasso Sea were found to be empty (Dragovich 1970). Thus, it remains plausible that for much of the time in these oligotrophic regions there are few foraging opportunities.

The prevalence of U-shaped diving behavior was used to identify putative foraging hotspots (Fig. 3c). There is 

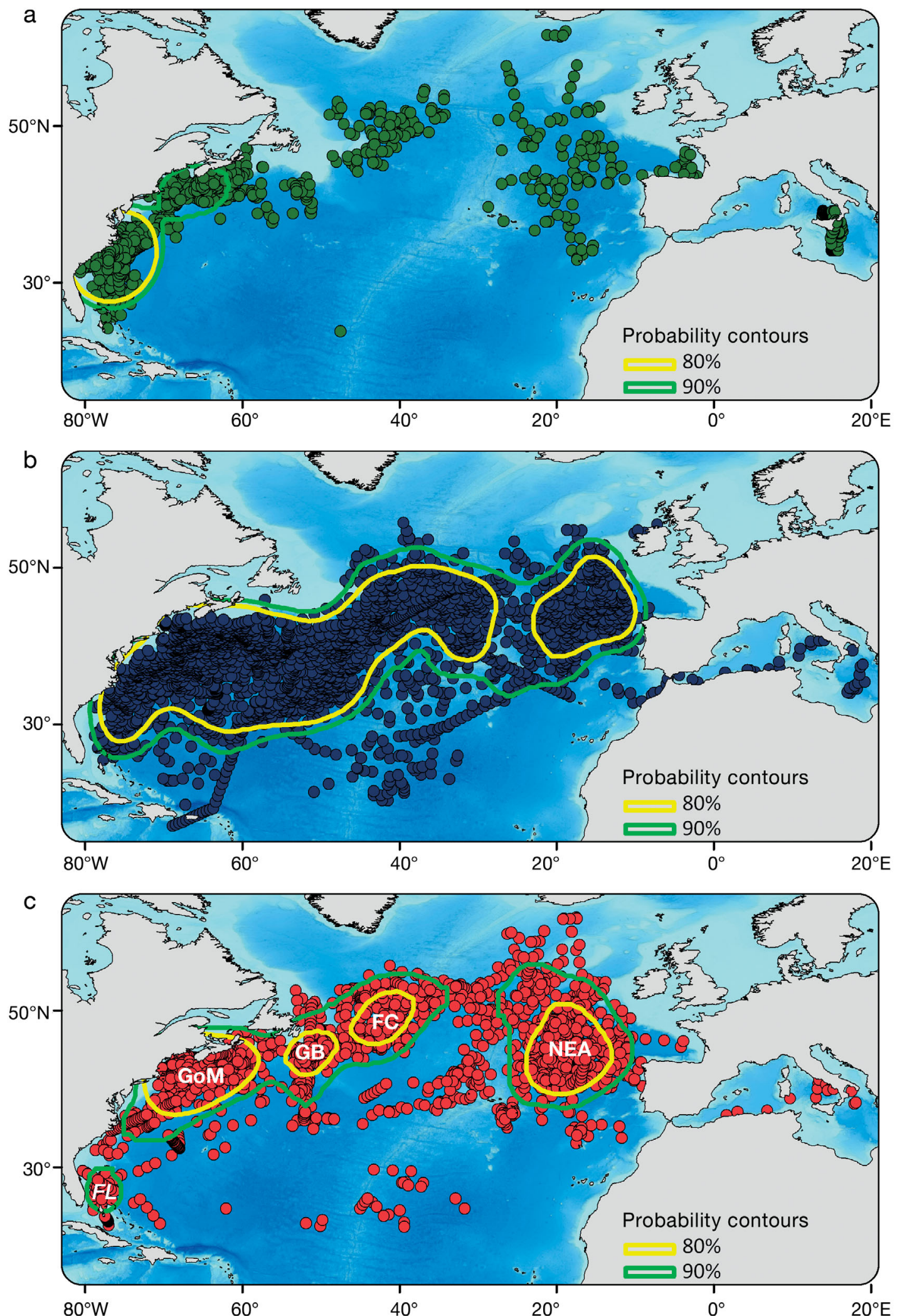

Fig. 3. Thunnus thynnus. Fixed kernel probability contours of (a) restricted profiles, (b) V-shaped profiles and (c) U-shaped profiles (all fish pooled) in the North Atlantic Ocean. GoM: Gulf of Maine/Scotian Shelf; GB: Grand Banks; FC: Flemish Cap; FL: Florida/Bahamas; NEA: NE Atlantic 

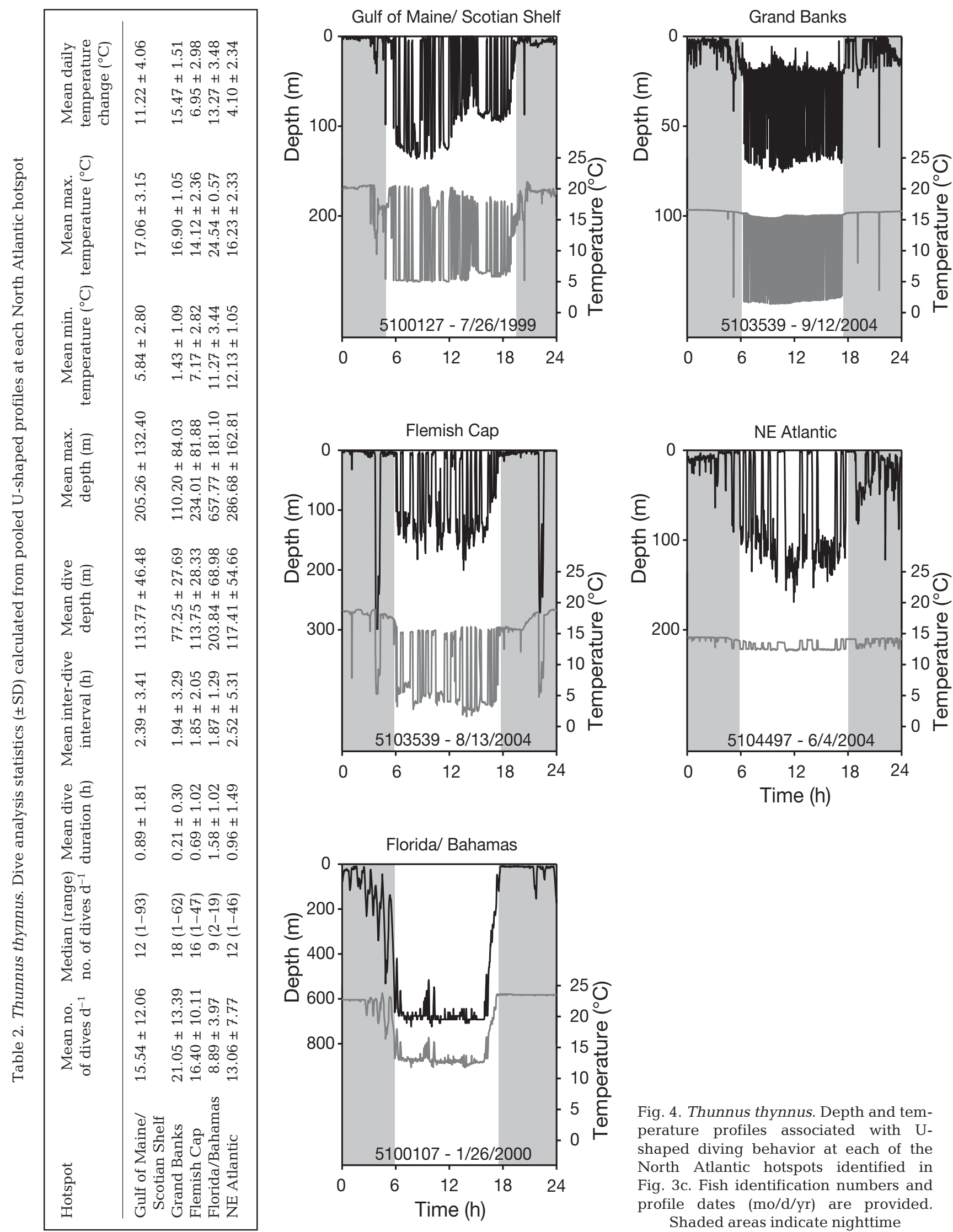

Fig. 4. Thunnus thynnus. Depth and temperature profiles associated with Ushaped diving behavior at each of the North Atlantic hotspots identified in Fig. 3c. Fish identification numbers and profile dates $(\mathrm{mo} / \mathrm{d} / \mathrm{yr})$ are provided. Shaded areas indicate nighttime 

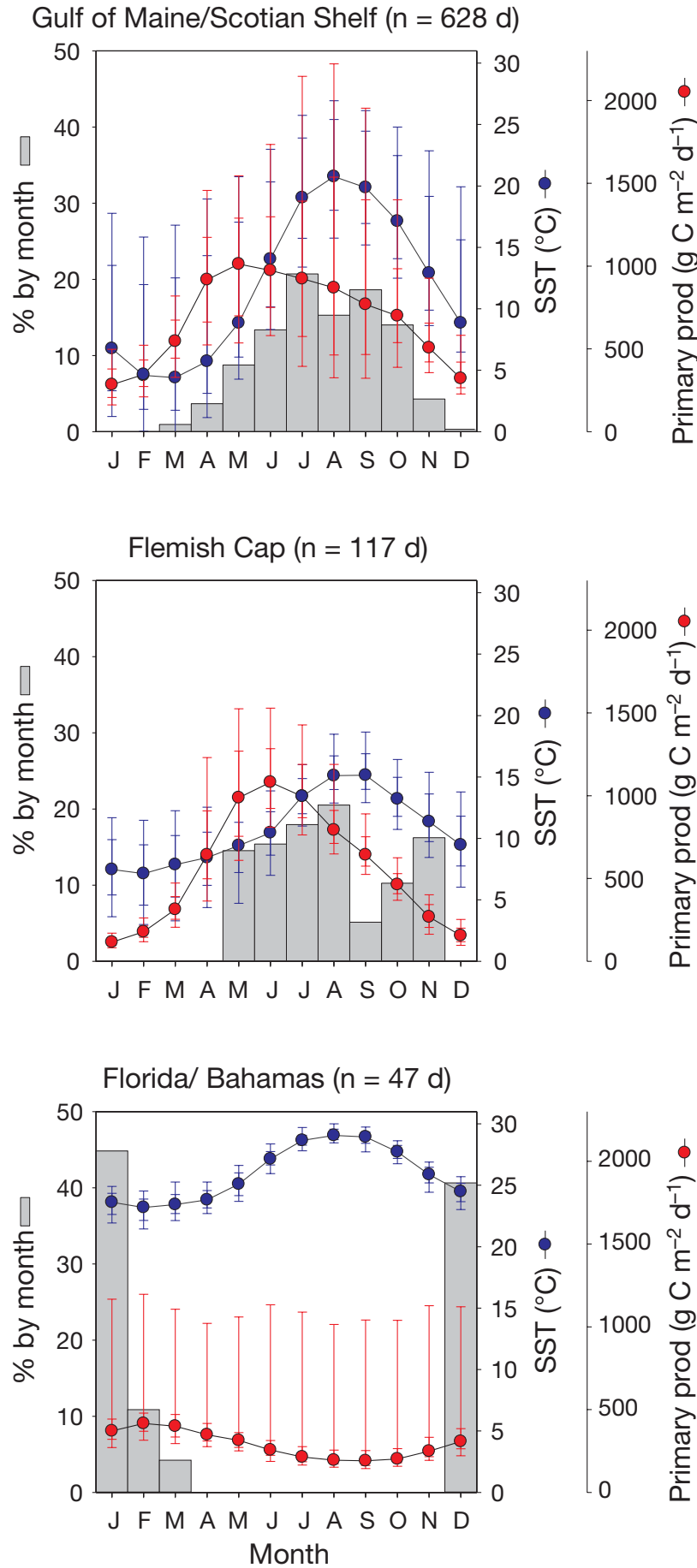

substantial evidence linking U-shaped diving to foraging in air-breathing marine vertebrates. For example, studies using stomach temperature data and underwater video have positively associated feeding events with Ushaped dive profiles in harbor seals Phoca vitulina and African penguins Spheniscus demersus (Wilson \& Wilson 1995, Lesage et al. 1999, Baechler et al. 2002). While there have been few studies directly linking dive behav-
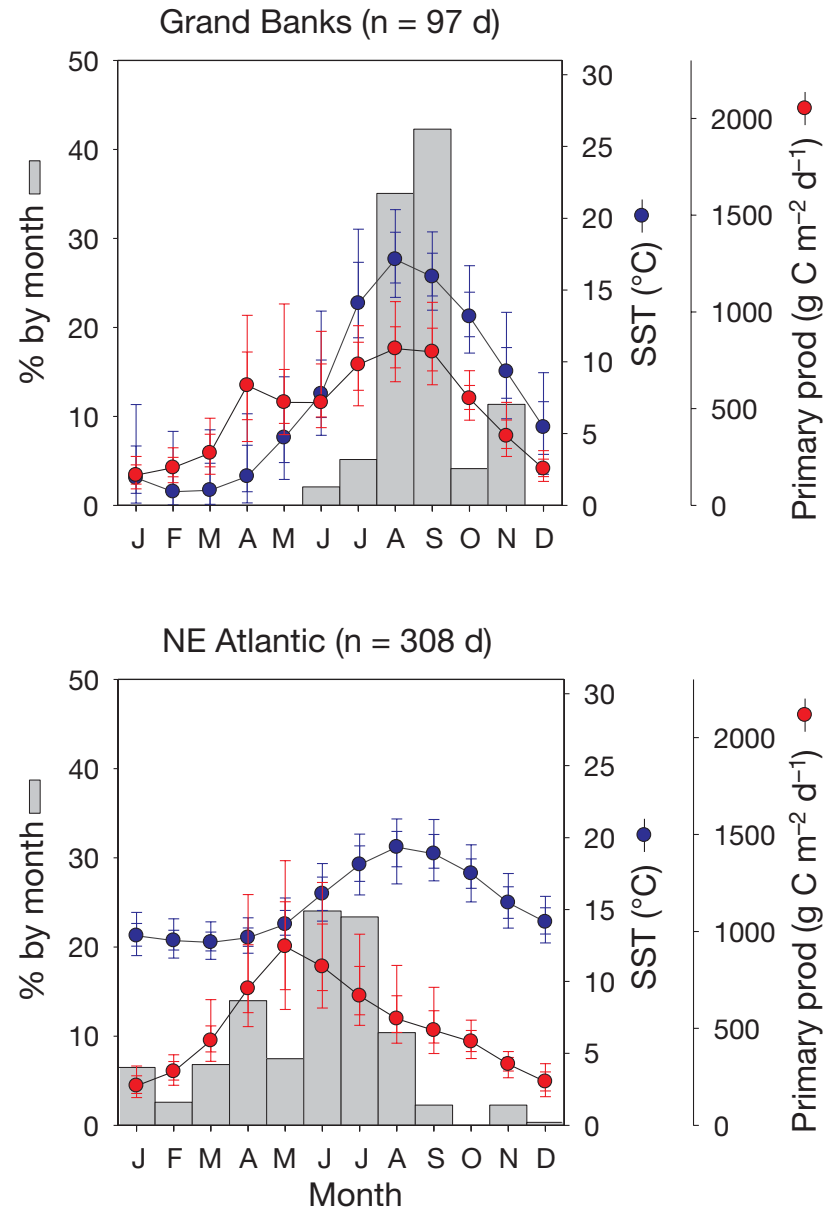

Fig. 5. Thunnus thynnus. Monthly presence of bluefin in relation to seasonal trends in primary productivity (primary prod; red circles) and sea surface temperature (SST; blue circles) within each of the North Atlantic hotspots identified in Fig. 3c. As the oceanographic data were skewed, the median, 10th, 25 th, 75th and 90th percentiles are given

ior to foraging in pelagic fishes (e.g. Josse et al. 1998), it is evident that individuals exhibiting U-shaped profiles have preferred daytime depths consistent with feeding on a layer of prey (Fig. 4).

Each of the 3 NW Atlantic hotspots, the Gulf of Maine/Scotian Shelf, Grand Banks and Flemish Cap, are recognized bluefin feeding areas (e.g. Mather et al. 1995, Block et al. 2001, Wilson et al. 2005, Walli 2007). 


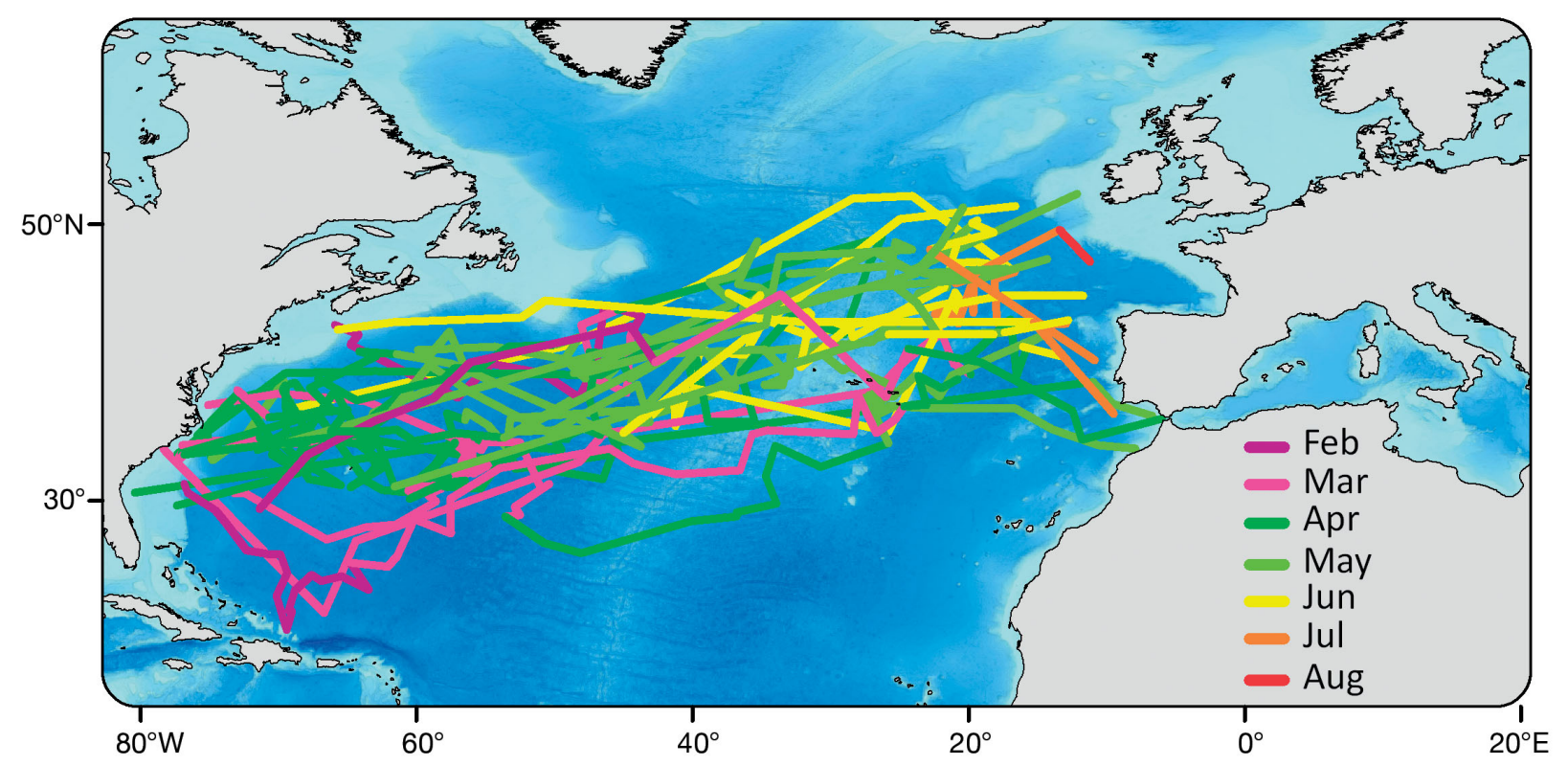

Fig. 6. Thunnus thynnus. Transatlantic routes taken by fish moving from west to east

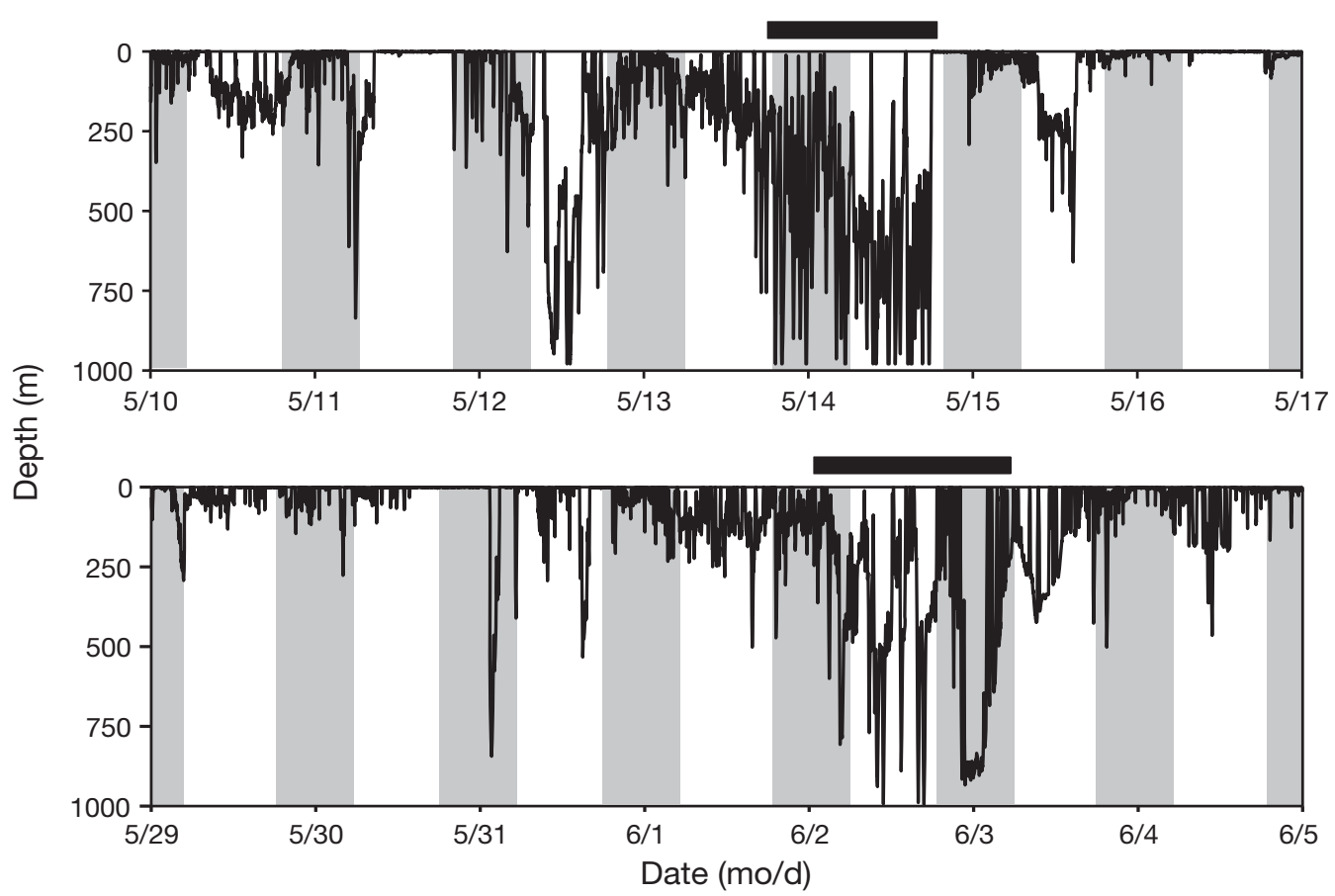

Fig. 7. Thunnus thynnus. One week V-shaped (transiting) dive profiles of 2 fish (5104559 and 5103508) passing from the Atlantic Ocean to the Mediterranean Sea. Shaded areas indicate nighttime, and bars at the top of each panel indicate when the fish were passing through the Strait of Gibraltar

The 2 remaining regions, waters off Florida and the Bahamas and the area identified in the NE Atlantic, are less well known, and bluefin catches have been historically low in these areas (Fromentin \& Powers 2005). While there are sporadic reports of significant longline catches of bluefin off the northern Bahamas (e.g. Rathjen 1961, Cramer \& Scott 1997), we found no indication of targeted fisheries in the NE Atlantic area. Tagging studies have shown that bluefin seasonally occupy these habitats (e.g. Block et al. 2001, 2005, Boustany et al. 2008).

We considered the possibility that the Florida/ Bahamas and NE Atlantic areas were occupied exclusively by western and eastern bluefin prior to and fol- 
lowing spawning in the Gulf of Mexico and Mediterranean Sea, respectively. Bluefin exhibiting putative foraging behavior off Florida and the Bahamas were of either western or unknown origin, indicating that those waters may be used by western fish prior to spawning. Remaining in warm waters before entering into spawning waters may have energetic advantages for mobilizing fat reserves into the eggs. It has also been suggested that Atlantic bluefin spawn in the Straits of Florida (Rivas 1954, McGowan \& Richards 1989). Bluefin exhibiting U-shaped dive profiles in the NE Atlantic hotspot area were found to be of eastern, western and unknown origin.

Dive statistics show that the vertical behavior of Atlantic bluefin tuna varies greatly between hotspots, possibly as a result of differences in oceanographic conditions (Table 2). In the NW Atlantic areas, occupied from late spring through fall, dives were generally short and shallow. Minimum temperatures experienced on those dives were lower than at the other locations. This contrasts with longer and deeper dives made off Florida and the Bahamas and in the NE Atlantic, where minimum temperatures were warmer despite greater depths. While the water column off Florida and the Bahamas is stratified, temperatures at depth remain relatively warm (Fig. 4). Similarly, leatherback turtles Dermochelys coriacea have been shown to dive deeper in tropical regions of the North Atlantic than in temperate areas (James et al. 2005). In the NE Atlantic region the mixed layer can extend to great depths (Fig. 4), providing bluefin with a thermally stable environment and access to deep-water prey. Several studies have found that Pacific and Atlantic bluefin tunas dive deeper in mixed water columns than in stratified waters (e.g. Kitagawa et al. 2000, Wilson et al. 2005, Lawson et al. 2010).

Physiological limitations may explain why cold, stratified waters restrict the bottom time of Atlantic bluefin and force surface returns. Archival tag data indicate that the internal temperature of large bluefin can routinely be from 12 to $20^{\circ} \mathrm{C}$ above ambient temperatures when diving in highly stratified waters (Gunn \& Block 2001, Lawson et al. 2010). Consequently, there is high oxygen demand in internal tissues when the bluefin cardio-respiratory system is exposed to cold ambient temperatures. Bluefin tunas are known to have a pronounced bradycardia response to cold temperatures (Blank et al. 2004, T. D. Clark \& B. A. Block unpubl. data). While the cardiac myocytes of bluefin have a broad eurythermal range of calcium pumping capacity, their ability to cycle calcium ions at extremely cold temperatures is diminished (Castilho et al. 2007). Recently, their cardiac myocytes have been shown to have a longer action potential at cold temperatures, demonstrating that the slowing of the heart has a cellular basis (Galli et al. 2009). Bluefin diving to extremely cold temperatures regularly return to warmer surface waters to increase cardiac output and recharge oxygen stores. Thus, underlying the pronounced bounce diving observed in some regions is a complex physiological set of relationships between internal temperature, oxygen stores and the thermal limitations of the cardiac system.

Differences in the diving behavior of bluefin may also result from different prey distributions and availability at the 5 hotspots. A shift from a predominantly piscivorous diet in the NW Atlantic hotspots to squid and other deep-water prey off Florida and the Bahamas and in the NE Atlantic may explain the differences in the diving behavior observed between these areas. The diet of juvenile southern bluefin tuna Thunnus maccoyii was found to be composed mainly of fish when on the continental shelf, and of squid and planktonic crustaceans when in offshore waters (Young et al. 1997).

In the Gulf of Maine, bluefin feed predominantly on neritic fishes, with sandlance Ammodytes americanus, Atlantic herring Clupea harengus and Atlantic mackerel Scomber scombrus among the most common prey items (Crane 1936, Chase 2002). In the Gulf of St. Lawrence, bluefin fishing grounds spatially overlap with those of Atlantic herring and mackerel (Jacques Whitford Environment Limited 2001). Capelin Mallotus villosus and squid were the major prey items identified in bluefin caught on the Grand Banks (Butler 1969). To date, there have been no feeding studies published on bluefin caught on the Flemish Cap.

In Bahamian waters, the most common prey items found in the stomachs of captured bluefin tuna were squid, salps, pelagic fishes and planktonic crustaceans (De Sylva 1956, Krumholz 1959, Dragovich 1970). Squid and small unidentified fish were found in the stomachs of bluefin caught in the NE Atlantic between Ireland and Iceland (Boyd 2008). A series of papers was recently published examining the diets of 5 pelagic predators inhabiting the NE Atlantic hotspot area (see Pusineri et al. 2008). One predator group, comprised of albacore tuna Thunnus alalunga, common dolphins Delphinus delphis and striped dolphins Stenella coeruleoalba, had elevated energy requirements and was found primarily in the epipelagic layer. They predominantly consumed small, gregarious epipelagic and vertically migrating mesopelagic fishes and squids of high energy content. A second predator group, containing swordfish and blue sharks Prionace glauca, led energetically cheaper lifestyles and was not constrained to the surface layer. They foraged on scattered, deep-living, large-size and low-energy fishes and squids. While bluefin tuna were not included in this analysis, they combine high energy 
needs with the physiological capabilities of exploiting cold, deep-water habitats.

The presence of bluefin in the Gulf of Maine/Scotian Shelf area and on the Flemish Cap did not coincide with a peak in primary productivity (Fig. 5). This may be attributable to the low SSTs $\left(<10^{\circ} \mathrm{C}\right)$ found at those locations during the spring bloom, or to a temporal lag between phytoplankton blooms and the presence of top predators. In contrast, bluefin were found in the other hotspot areas when they were most productive. On the Grand Banks, maximum primary production occurred in the late summer when SSTs were $>10^{\circ} \mathrm{C}$. Off Florida and the Bahamas and in the NE Atlantic, SSTs do not drop below that threshold. Thus, there emerges a balance between the thermal limitations of bluefin and their prey, production and the overlap in appearance of the fish in distinct oceanic regimes.

Transatlantic movements of bluefin tuna have been documented in numerous conventional (e.g. Mather 1980) and electronic tagging studies (e.g. Block et al. 2005). The spatial and temporal patterns of the west to east crossings reported here (Fig. 6) are generally consistent with those found through conventional tag deployments (Mather 1980). It has long been suspected that migrating bluefin use the Gulf Stream Current to assist their west to east movements (Sella 1929). Furthermore, it has been suggested that interannual variability in westerly winds may account for differences in the rate of these crossings (Rodewald 1967). The transatlantic routes are more southerly earlier in the year because fish are distributed in warmer waters located farther to the south (off the Carolinas) when initiating their crossings.

Deep dives made by bluefin when approaching the Mediterranean Sea (Fig. 7) may function to locate Mediterranean outflow water and thus guide the fish through the Strait of Gibraltar. Lighter, fresher Atlantic waters form the inflowing surface layer of the passage, while denser, saline Mediterranean waters form the outflowing bottom layer (Price et al. 1993). Alternatively, these dives may be related to predator avoidance, as killer whales Orcinus orca are known to prey on bluefin as they migrate through the narrow Strait of Gibraltar (Guinet et al. 2007), or foraging on squid and fishes inhabiting deep Mediterranean outflow waters (De Stephanis et al. 2008). Similar deep diving has been found in Atlantic bluefin tuna entering and exiting the Gulf of Mexico spawning grounds (Stokesbury et al. 2004, Teo et al. 2007a). Other possible explanations for this behavior include thermoregulation and energetic savings associated with avoiding an ocean current (Teo et al. 2007a).

Marine biodiversity is threatened by global climate change and overfishing. The ability to recognize the function of key habitats, including those essential for breeding and foraging, is critical to understanding the processes that concentrate animals and increase their vulnerability. Thus, spatial analysis of the distribution of dive profiles may be a useful tool when identifying potential marine protected areas. These regions will become critical focal points for conservation in the high seas management of heavily exploited fisheries such as Atlantic bluefin tuna.

Acknowledgements. We thank the Tag-A-Giant program's scientific team, including A. Boustany, S. Teo, C. Farwell, R. Schallert, J. Noguiera, L. Rodriguez and many others, for their efforts in generating the data sets used here. We are also grateful to the captains and crews of all participating vessels. G. Lawson, P. Kim, J. Ganong and M. Castleton provided code for analysis and much appreciated technical assistance. Tag recovery was facilitated by the National Marine Fisheries Service. Funding was provided by NOAA, the Tag-A-Giant Foundation and the Monterey Bay Aquarium Foundation.

\section{LITERATURE CITED}

Baechler J, Beck CA, Bowen WD (2002) Dive shapes reveal temporal changes in the foraging behaviour of different age and sex classes in harbour seals (Phoca vitulina). Can J Zool 80:1569-1577

Behrenfeld MJ, Falkowski PG (1997) Photosynthetic rates derived from satellite-based chlorophyll concentration. Limnol Oceanogr 42:1-20

Bestley S, Patterson TA, Hindell MA, Gunn JS (2008) Feeding ecology of wild migratory tunas revealed by archival tag records of visceral warming. J Anim Ecol 77:1223-1233

Blank JM, Morrissette JM, Landeira-Fernandez AM, Blackwell SB, Williams TD, Block BA (2004) In situ cardiac performance of Pacific bluefin tuna hearts in response to acute temperature change. J Exp Biol 207:881-890

Block BA, Dewar H, Williams T, Prince ED, Farwell C, Fudge D (1998a) Archival tagging of Atlantic bluefin tuna (Thunnus thynnus thynnus). Mar Technol Soc J 32:37-46

Block BA, Dewar H, Farwell C, Prince ED (1998b) A new satellite technology for tracking the movements of Atlantic bluefin tuna. Proc Natl Acad Sci USA 95:9384-9389

Block BA, Dewar H, Blackwell SB, Williams TD and others (2001) Migratory movements, depth preferences, and thermal biology of Atlantic bluefin tuna. Science 293: 1310-1314

Block BA, Teo SLH, Walli A, Boustany A and others (2005) Electronic tagging and population structure of Atlantic bluefin tuna. Nature 434:1121-1127

Boustany AM, Reeb CA, Block BA (2008) Mitochondrial DNA and electronic tracking reveal population structure of Atlantic bluefin tuna (Thunnus thynnus). Mar Biol 156: $13-24$

Boyd J (2008) The Japanese bluefin tuna longline fishery in the northeast Atlantic: report of an Irish observer. Irish Fisheries Investigations 20. Available at: www.marine.ie/NR/ rdonlyres/DEA8750D-5456-4AF6-B2D7-8CA879983AA9/ 0/TunaFinalReport2.pdf

Butler MJA (1969) A contribution to the biology of Thunnus thynnus (Linnaeus, 1758), in Conception Bay, Newfoundland. MSc thesis, Memorial University of Newfoundland, St. John's, NL

Castilho PC, Landeira-Fernandez AM, Morrissette J, Block BA (2007) Elevated $\mathrm{Ca}^{2+}$ ATPase (SERCA2) activity in tuna 
hearts: comparative aspects of temperature dependence. Comp Biochem Physiol A 148:124-132

Chase BC (2002) Differences in diet of Atlantic bluefin tuna (Thunnus thynnus) at five seasonal feeding grounds on the New England continental shelf. Fish Bull (Wash DC) 100:168-180

$>$ Chilvers BL, Delean JSC, Gales NJ, Holley DK, Lawler IR, Marsh HD, Preen AR (2004) Diving behaviour of dugongs, Dugong dugon. J Exp Mar Biol Ecol 304:203-224

Cramer J, Scott GP (1997) Standardized catch rates for large bluefin tuna, Thunnus thynnus, from the U.S. pelagic longline fishery in the Gulf of Mexico and off the Florida east coast. ICCAT Coll Vol Sci Pap 46:246-251

Crane J (1936) Notes on the biology and ecology of giant tuna Thunnus thynnus, L., observed at Portland, Maine. Zoologica 212:207-212

Crocker DE, Costa DP, Le Boeuf BJ, Webb PM, Houser DS (2006) Impact of El Niño on the foraging behavior of female northern elephant seals. Mar Ecol Prog Ser 309: 1-10

Croll DA, Acevedo-Gutiérrez A, Tershy B, Urbán-Ramírez J (2001) The diving behavior of blue and fin whales: Is dive duration shorter than expected based on oxygen stores? Comp Biochem Physiol A 129:797-809

De Stephanis R, Cornulier T, Verborgh P, Salazar Sierra J, Pérez Gimeno N, Guinet C (2008) Summer spatial distribution of cetaceans in the Strait of Gibraltar in relation to the oceanographic context. Mar Ecol Prog Ser 353: $275-288$

De Sylva D (1956) The food of tunas. Bull Int Oceanogr Found 2:37-48

> Dragovich A (1970) The food of bluefin tuna (Thunnus thynnus) in the western North Atlantic Ocean. Trans Am Fish Soc 99:726-731

Elliott KH, Woo K, Gaston AJ, Benvenuti S, Dall'Antonia L, Davoren GK (2008) Seabird foraging behaviour indicates prey type. Mar Ecol Prog Ser 354:289-303

Fossette S, Gaspar P, Handrich Y, Le Maho Y, Georges JY (2008) Dive and beak movement patterns in leatherback turtles Dermochelys coriacea during internesting intervals in French Guiana. J Anim Ecol 77:236-246

Fromentin JM, Powers JE (2005) Atlantic bluefin tuna: population dynamics, ecology, fisheries and management. Fish Fish 6:281-306

Galli GLJ, Lipnick M, Block BA (2009) The effect of thermal acclimation on action potentials and sarcolemmal $\mathrm{K}^{+}$channels from Pacific bluefin tuna cardiomyocytes. Am J Physiol Regul Integr Comp Physiol 297:R502-R509

> Guinet C, Domenici P, de Stephanis R, Barrett-Lennard L, Ford JKB, Verborgh P (2007) Killer whale predation on bluefin tuna: exploring the hypothesis of the enduranceexhaustion technique. Mar Ecol Prog Ser 347:111-119

Gunn J, Block B (2001) Advances in acoustic, archival and satellite tagging of tunas. In: Block BA, Stevens ED (eds) Tuna: physiology, ecology and evolution. Academic Press, San Diego, CA, p 167-224

Hassrick JL, Crocker DE, Zeno RL, Blackwell SB, Costa DP, Le Boeuf BJ (2007) Swimming speed and foraging strategies of northern elephant seals. Deep-Sea Res 54:369-383

Hays GC (2008) Sea turtles: a review of some key recent discoveries and remaining questions. J Exp Mar Biol Ecol $356: 1-7$

- Hays GC, Adams CR, Broderick AC, Godley BJ, Lucas DJ, Metcalfe JD, Prior AA (2000) The diving behaviour of green turtles at Ascension Island. Anim Behav 59:577-586

Hays GC, Doyle TK, Houghton JDR, Lilley MKS, Metcalfe JD, Righton D (2008) Diving behaviour of jellyfish equipped with electronic tags. J Plankton Res 30:325-331
Hooge PN, Eichenlaub B (2000) Animal movement extension to Arcview. Alaska Science Center-Biological Science Office, US Geological Survey, Anchorage, AK

> Huin N, Prince PA (1997) Diving behaviour of the greyheaded albatross. Antarct Sci 9:243-249

Jacques Whitford Environment Limited (2001) Atlas of ecologically and commercially important areas in the southern Gulf of St. Lawrence. ESRF Report 140, Environmental Studies Research Funds, Calgary, AB

James MC, Myers RA, Ottensmeyer CA (2005) Behaviour of leatherback sea turtle, Dermochelys coriacea, during the migratory cycle. Proc R Soc Lond B Biol Sci 272:1547-1555

> Josse E, Back P, Dagorn L (1998) Simultaneous observations of tuna movements and their prey by sonic tracking and acoustic surveys. Hydrobiologia 371/372:61-69

> Kitagawa T, Nakata H, Kimura S, Itoh T, Tsuji S, Nitta A (2000) Effect of ambient temperature on the vertical distribution and movement of Pacific bluefin tuna Thunnus thynnus orientalis. Mar Ecol Prog Ser 206:251-260

> Kitagawa T, Kimura S, Nakata H, Yamada H (2004) Diving behavior of immature, feeding Pacific bluefin tuna (Thunnus thynnus orientalis) in relation to season and area: the East China Sea and the Kuroshio-Oyashio transition region. Fish Oceanogr 13:161-180

Kooyman GL (1968) An analysis of some behavioral and physiological characteristics related to diving in the Weddell seal. In: Llano GA, Schmitt WL (eds) Biology of the Antarctic seas. Antarctic Research Series, Vol 3. American Geophysical Union, Washington, DC, p 227-261

Krumholz LA (1959) Stomach contents and organ weights of some bluefin tuna, Thunnus thynnus (Linnaeus), near Bimini, Bahamas. Zoologica 44:127-131

> Lawson GL, Castleton MR, Block BA (2010) Movements and diving behavior of Atlantic bluefin tuna Thunnus thynnus in relation to water column structure in the northwestern Atlantic. Mar Ecol Prog Ser 400:245-265

Lesage V, Hammill MO, Kovacs KM (1999) Functional classification of harbor seal (Phoca vitulina) dives using depth profiles, swimming velocity, and an index of foraging success. Can J Zool 77:74-87

> Lescroël A, Bost CA (2005) Foraging under contrasting oceanographic conditions: the gentoo penguin at Kerguelen Archipelago. Mar Ecol Prog Ser 302:245-261

Malcolm CD, Duffus DA (2000) Comparison of subjective and statistical methods of dive classification using data from a time-depth recorder attached to a gray whale (Eschrichtius robustus). J Cetacean Res Manag 2:177-182

> Martin AR, Kingsley MCS, Ramsay MA (1994) Diving behaviour of narwhals (Monodon monoceros) on their summer grounds. Can J Zool 72:118-125

Mather FJ (1980) A preliminary note on migratory tendencies and distributional patterns of Atlantic bluefin tuna on recently acquired and cumulative tagging results. ICCAT Coll Vol Sci Pap 9:478-490

Mather FJ, Mason JM, Jones AC (1995) Historical document: life history and fisheries of Atlantic bluefin tuna. NOAA Tech Mem NMFS-SEFSC 370

McGowan MF, Richards WJ (1989) Bluefin tuna, Thunnus thynnus, larvae in the Gulf Stream off the southeastern United States: satellite and shipboard observations of their environment. Fish Bull (Wash DC) 87:615-631

NRC (National Research Council) (1994) An assessment of Atlantic bluefin tuna. NRC, National Academy Press, Washington, DC

Price JF, O'Neil Baringer M, Lueck RG, Johnson GC and others (1993) Mediterranean outflow mixing and dynamics. Science 259:1277-1282 
Pusineri C, Chancollon O, Ringelstein J, Ridoux V (2008) Feeding niche segregation among the Northeast Atlantic community of oceanic top predators. Mar Ecol Prog Ser 361:21-34

Rathjen WF (1961) Memorandum. US Department of the Interior, Bureau of Commercial Fisheries, Exploratory Fishing and Gear Research Base, Gloucester, MA

Rivas LR (1954) A preliminary report on the spawning of the western North Atlantic bluefin tuna (Thunnus thynnus) in the Straits of Florida. Bull Mar Sci Gulf Caribb 4:302-322

Rodewald M (1967) Transatlantic migrations of the bluefin tuna and the anomalies of the atmospheric circulation. ICES Comm Meet J:7:1-5

Rooker JR, Alvarado Bremer JR, Block BA, Dewar H and others (2007) Life history and stock structure of Atlantic bluefin tuna (Thunnus thynnus). Rev Fish Sci 15:265-310

Schaefer KM, Fuller DW, Block BA (2007) Movements, behavior, and habitat utilization of yellowfin tuna (Thunnus albacares) in the northeastern Pacific Ocean, ascertained through archival tag data. Mar Biol 152:503-525

Schreer JF, Testa JW (1995) Statistical classification of diving behaviour. Mar Mamm Sci 11:85-93

Schreer JF, Testa JW (1996) Classification of Weddell seal diving behaviour. Mar Mamm Sci 12:227-250

Schreer JF, O'Hara Hines RJ, Kovacs KM (1998) Classification of dive profiles: a comparison of statistical clustering techniques and unsupervised artificial neural networks. J Agric Biol Environ Stat 3:383-404

Schreer JF, Kovacs KM, Hines RJO (2001) Comparative diving patterns of pinnipeds and seabirds. Ecol Monogr 71: $137-162$

Sella M (1929) Migrazioni e habitat del tonno studiati col metodo degli ami, con osservazioni su l'acrescimento sul regime delle tonnare, ecc. Mem R Comit Talass Ital 156: 511-542

Silverman BW (1986) Density estimation for statistics and data analysis. Chapman \& Hall, London

Spencer SR, Cameron GN, Swihart RK (1990) Operationally defining home range: temporal dependence exhibited by hispid cotton rats. Ecology 71:1817-1822

Stokesbury MJW, Teo SLH, Seitz A, O'Dor RK, Block BA (2004) Movement of Atlantic bluefin tuna (Thunnus thynnus) as determined by satellite tagging experiments initiated off New England. Can J Fish Aquat Sci 61:1976-1987

Teo SLH, Boustany AM, Blackwell S, Walli A, Weng KC, Block BA (2004) Validation of geolocation estimates based

Editorial responsibility: Brendan Godley,

University of Exeter, Cornwall Campus, UK on light level and sea surface temperature from electronic tags. Mar Ecol Prog Ser 283:81-98

Teo SLH, Boustany A, Dewar H, Stokesbury MJW and others (2007a) Annual migrations, diving behavior, and thermal biology of Atlantic bluefin tuna, Thunnus thynnus, on their Gulf of Mexico breeding grounds. Mar Biol 151:1-18

> Teo SLH, Boustany AM, Block BA (2007b) Oceanographic preferences of Atlantic bluefin tuna, Thunnus thynnus, on their Gulf of Mexico breeding grounds. Mar Biol 152: 1105-1119

> Thompson D, Hammond PS, Nicholas KS, Fedak MA (1991) Movements, diving and foraging behaviour of grey seals. J Zool (Lond) 224:223-232

> Tinker MT, Costa DP, Estes JA, Wieringa N (2007) Individual dietary specialization and dive behaviour in the California sea otter: using archival time-depth data to detect alternative foraging strategies. Deep-Sea Res II 54:330-342

Walli AG (2007) On the movements, aggregations and the foraging habitat of bluefin tuna (Thunnus thynnus and orientalis). PhD thesis, University of California, Santa Cruz, CA

Walli A, Teo SLH, Boustany A, Farwell CJ and others (2009) Seasonal movements, aggregations and diving behavior of Atlantic bluefin tuna (Thunnus thunnus) revealed with archival tags. PLoS ONE 4:e6151

Williams TM, Kooyman GL (1985) Swimming performance and hydrodynamic characteristics of harbor seals Phoca vitulina. Physiol Zool 58:576-589

Wilson RP, Wilson MP (1995) The foraging behaviour of the African Penguin. In: Dann P, Norman I, Reilly P (eds) The penguins: ecology and management. Surrey Beatty and Sons, Chipping Norton, NSW, p 244-265

Wilson RP, Culik BM, Peters G, Bannasch R (1996) Diving behaviour of Gentoo penguins, Pygoscelis papua; factors keeping dive profiles in shape. Mar Biol 126:153-162

Wilson SG, Lutcavage ME, Brill RW, Genovese MP, Cooper AB, Everly AW (2005) Movements of bluefin tuna (Thunnus thynnus) in the northwestern Atlantic Ocean recorded by pop-up archival tags. Mar Biol 146:409-423

Young JW, Lamb TD, Le D, Bradford RW, Whitelaw AW (1997) Feeding ecology and interannual variations in diet of southern bluefin tuna, Thunnus maccoyii, in relation to coastal and oceanic waters off eastern Tasmania, Australia. Environ Biol Fishes 50:275-291

Submitted: March 13, 2009; Accepted: September 25, 2009 Proofs received from author(s): December 8, 2009 